\title{
On De Stijl and Architectural Design
}

\author{
Siying Qin \\ Heihe University \\ Heihe, China
}

\begin{abstract}
Based on the analysis of and research on the expressive characteristics of De Stijl in Netherlands, the paper points out that the influence of the Dutch De Stijl not only manifests itself in the architectural works of some master architects, but also appears in the education of architecture. Thus, the influence of De Stijl on architecture design will live forever.
\end{abstract}

Keywords-De Stijl; architecture; color; 4-Dimension Decompound

\section{INTRODUCTION}

The Dutch De Stijl, an important modernist movement in the early 20th century, differed from some other movements having clear themes and complete organizational structures, having no complete structure and systematic manifestos and existing for only 14 years. However, it had a big impact on subsequent modern artistic design, architecture design, home design, etc. It was considered one of the bases of "Classic Modernism".

\section{ANALYSIS OF THE EXPRESSIVE CHARACTERISTICS OF DE STIJL}

Born in World War One, De Stijl, in its early days, had distinct expressive features. For instance, they argue to completely strip off the characteristics of traditional architecture, furniture and product design, painting and sculpture to make them the most fundamental geometric monomers, or elements, as they called. These monomers or elements are then combined to be simple structure combinations. In the new structure combinations, however, the monomers still keep relatively independent and clearly visible. They persist in in-depth research and application of asymmetry, and in particularly repeated use of crisscrossed geometric structures, basic primary colors and neutral colors. These views have impacts not only on the painting of De Stijl artists and the artistic creation of sculptors, but also on the design of some architects and planners, some classic works of architecture being created accordingly.

\section{DE STIJL's IMPACTS ON ARCHITECTURE DESIGN}

The De Stijl architect Oud designed "Union Café" in Rotterdam has a strong flavor of constructivism. In terms of the façade design, he well interpreted his theme by use of large areas of color contrast and accurate and harmonious detail percentage as well as an addition of a concise and vivid style of form. For his another work, the Spangen House, he employed the repeat formation of simple shapes to create a simple and pragmatic domestic unit. Of course, the most well-known De Stijl work of architecture should be the Gehry Rietveld-designed Utrecht Schroeder House. The house, element-based, economical, functional, nonmonumental, dynamic, anti-cubic in form and antidecorative in color, is the incarnation of Theodore van Doesburg's theory of plastic construction in architecture. Its façade, like a work of three-dimensional construction, consists of crisscrossed blocks of different size, which are mutually governed and independent, and so perfect in proportion and so appropriate in location that anyone even having a glance at them will be overwhelmed. The Utrecht Schroeder House is not only ingenious in the shape design, but also very fresh in the inner space treatment. It has open and transformable spatial arrangement, flexible collapsible walls and thorough internal and external space communication relationships, etc. All of these made it the most modern house in Europe then. It was side even Walter Gropius and Corbusier paid a visit to it.

Theodore Van Doesburg is a De Stijl icon, not only a leader of De Stijl, but also an important theoretician of the school. He has personally involved in design and completion of many excellent architectural works. In 1923, he designed the "Home of Artists" for the Rosenberg Exhibition, Paris and made its model. In the same year, he published an important theoretical article of De Stijl-16 Points of the Art of Plastic Construction. In the article he wrote: "A new building should be anti-cubic. That is to say, it does not attempt to freeze different functional space cells into an enclosed cub. On the contrary, it centrifugally throws off functional space cells (as well as suspension planes, balcony volume, etc.) from the core of a cub. By this means, the height, width, depth and time (i.e. a conceived fourdimensional entirety) approach in an open space an all-new plastic expression. Thus, a building will have a kind of or somewhat levitation, resisting against the action of gravity". This article can be regarded as an important declaration of De Stijl in the field of architectural design. From the word "centrifugally" mentioned by Theodore Van Doesburg in the article, we can see a coincidence with the centrifugal space shown in the works of Mies and Wright. In 1928, Theodore Van Doesburg worked together with Hans and Sophie Taupo App to design the Orbit Restaurant located in Strasbourg. In the plan, he intentionally made use of many diagonal formative elements, made allocation or distortion by large bevel embossment or "counter-composition" lines and strengthened the position of color in architecture, thus attaining vivid visual characteristics. The Orbit Restaurant was the last significant work of architecture of Neoplasticism. 
From then on, every artist still belonging to De Stijl, including Theodore Van Doesburg and Piet Rietveld, is increasingly subject to the influence of Neue Sachlichkeit to submit to the cultural value of International Socialism. The influence of De Stijl not only manifests itself in the works of the members of the De Stijl school, but we also can see its tinge in the works of other master architects, for example, the Barcelona Pavilion designed by Mies van der Rohe. The Barcelona Pavilion is a milestone of modern architecture, an important turning point of Mies's design career and the epitome of his design idea "less is more" as well. The pavilion is not very large, measuring only $17 \mathrm{~m}$ by $53.6 \mathrm{~m}$, but its inner space is designed distinctively, one portion being indoors and one portion outdoors, both intercommunicated to be one. The roof is the then advanced reinforced concrete thin flat top, supported by nickel-plated steel columns. The interior employs light brown onyx marble, green Tinian marble and translucent thin walls as partitions. Outside there is a rectangular pool. A sculpture "The Dancer" designed by Georg Golby was placed aside as a decoration. The pavilion, very flexible in its plan design, adopts a horizontal and centrifugal spatial arrangement. The walls, combined through vertical and parallel relations in a very free manner, are both independent of each other and related to each other. Such way of combination of planes and space reminds us of the representative works of De Stijl.

The basic way of the 4-dimension decompound is to decompose the enveloping members of a building into sidings in different directions, and the sidings are restructured through different patterns of combination to be varied elements of a building. "Once the boundaries are broken down to be independent, they will expand upwards or downwards the scope of the original box to break the boundary always used to separate the internal space from the external..." [1]. "Once the box is decomposed, its panels will be not a part of a restricted space any more, but to form a stream-like, integral and continuously dynamic space. With the involvement of time, the dynamic space will replace the classical static space". From the expiation of 4-dimension decompound made by Bruno Zevi, we can see the relation between Mies's flowing space idea and the 4-dimension decompound. Thus, as it were, Mies's Barcelona Pavilion is another successful experiment of 4-dimension decompound in modernistic architectural design and a testimony to the relationship between this work of Mies and the Dutch De Stijl. We not only can see a sign of De Stijl in the works of Mies van der Rohe, but even also can find the origins of his academic activities of architecture in De Stijl.

In 1923, Mies van der Rohe was involved in the first issue of a Germany's avant-garde magazine G, Basic Modeling Data in full name, edited by Hans Lequite, Wiener Glaive and Lissitzky. Lissitzky is none other than one of the important representative figures of Russian constructivism. $\mathrm{He}$, together with the organizer of Dutch De Stijl, van Doesburg, attended the convention of International Constructivism and Dadasim held by the Bauhaus School in Dusseldorf. One the meeting, they introduced various views and opinions of pure form to form the new concepts of International Constructivism. Therefore, Mies who involved in the first issue of the magazine $\mathrm{G}$ one year later must have been significantly influenced by Constructivism and De Stijl. This can be proven from the monument designed by Mies for the Communist Liebknecht and his wife Luxemburg.

\section{DE STIJL'S IMPACTS ON CONTEMPORARY ARCHITECTURAL DESIGN}

Among the currently popular thoughts of architecture, De Stijl still has influence. The works of this kind mostly employ asymmetric structures, bear laconic basic forms, emphasize the formation of architectural blocks, show delicate and rigorous proportions and highlight the representation function of color. Take the Feng Jicai Institute of Literature and Art of Tianjing University (figure 3) designed by Mr. Zhou Kai for example, it is, in my opinion, a gorgeous work of modern new De Stijl. This building is simple and natural in form. The horizontal and vertical lines crisscross on the façade to give an aesthetic visual effect. The use of diagonal lines in the plan design makes the space of the building more flexible and pregnant with wisdom and vigor. De Stijl has its influence not only reflected in the works of the masters, but also revealed in architectural education. In 1921, after moving the magazine De Stijl to Bauhaus, Weimar, van Doesburg was employed at Bauhaus in April of the same year. Although his teaching in Weimar is not desirable, his ideas of rational expression and strict structural orders bring a positive impact on Bauhaus, making Bauhaus' teaching philosophy transit to rationalism. This, as it were, also fuels the birth and growth of modernistic architecture.

\section{CONCLUSION}

In brief, as one of the bases of modernism, De Stijl has an impact on every aspect of architecture. Up until now, the undergraduates studying architecture design have still received plane composition as their first specialized course, and then color composition, three-dimensional composition and space composition. The teachers talking of the history of "composition" would still refer to the representative figures of De Stijl, such as Piet Mondrian, Gehry Rietveld, Theodore van Doesberg. Mondrian's Composition of Red, Yellow, Blue and Black and Rietveld's Utrecht Schroeder House are well-known works for students. Thus, the influence of De Stijl on architectural education is, so to speak, everlasting, so it is on architectural design.

\section{REFERENCES}

[1] Bruno Zevi, Modern Architectural Language [M], Translated by Xi Yunping, Wang Hong. Beijing: China Architecture \& Building Press, 1986:32

[2] Lu Huling, Wang Jun, Sun Chengquan. On Architectural Art [J]. Shanxi Architecture, 2007, 33(7): 64-65. 